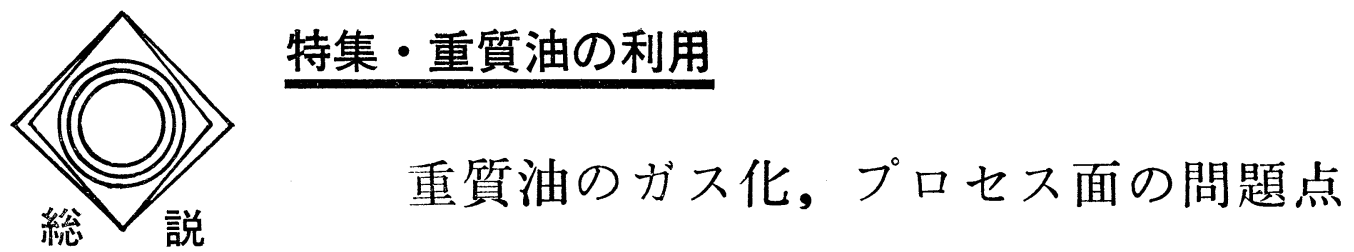

-1977. 12. 22 受理一

宇部興 産 侏* 河野尚志

\section{1.はじめに}

重質油のガス化の研究が注目され, わが国で開発研 究が盛んに実施されたのは, 昭和 40 年代に入ってから である。経済成長の著しい進展に伴って, 昭和40年か ら48年のエネルギー危機までにェネルギーの消費量が $218 \times 10^{6} \mathrm{t}$ C. E. (Coal Equivalent) から $472 \times 10^{6} \mathrm{t}$ C. E. とわずか 7 年間に 2 倍以上になり ${ }^{1)}$, 原油の輸 入量も $82 \times 10^{6} \mathrm{kl}$ から $246 \times 10^{6} \mathrm{kl}$ に約 3 倍になり1， 石油化学のエチレンセンターが各地に建設され, エチ レン生産量は約 5 倍になっている。重質油のガス化は, これらの経済的背景によって生じたプロセスニードで あると把握される。その意図するものとして, 主とし て次の 3 つの方向があった。

（1）過密地域，コンビナート地域を中心とする低硫 黄化対策として, 水素化脱硫（直脱, 間脱）で技術 的に処理の難しい減压残椬油その他からクリーンな ガス然料を得る2)。

（2）石油化学の著しい生産の増加に伴い, ナフサの 不足の状況の対策として, 重質油（原油, 常圧特よ び減圧残渣油)よりオレフィン原料ガスを得る ${ }^{3)-6) 。 ~}$

（3）石油精製システム中に打ける軽質化対策として 広義の意味の重質油のガス化をシステムにとり入れ る7。また，低硫黄化和よび軽質化用に精製システ ム内部での水素需要の增大に対応して, 重質油から 合成ガス，水素を製造する ${ }^{899}$ 。

これらのことからもわかるように, “重質油”“ガス 化”いずれも個々の場合によって内容がかなり異な る。すなわら, 反応温度のレベルで $500^{\circ} \mathrm{C}$ のコーキン グ反応, $800^{\circ} \mathrm{C}$ のクラッキング反応, $900 \sim 1000^{\circ} \mathrm{C}$ のス チームリホーミング反応和よび1300〜 $1400^{\circ} \mathrm{C}$ の合成ガ ス化反応を含んでいる。重質油についても, 主として

* 宇部市大字小串1978番地の 5
減圧，常圧残渣油を指すことが多いが，プロセスによ って同じではない10)。

さて, 重質油のガス化の今後を考光る場合, 重質油 の量および質は, 石油精製システム全体の計画の中で の結果量であることを考えると, 当然のことであるが 石油精製システムに挔ける需要構造, 軽質化技術の動 向が重要な意味をもってくる。石油の消費量, 需要構 造の今後の子測は, ェネルギー, 資源問題の中心にな る性質の難しい問題であるが, 従来二, 三の報告はあ る(10) 12) があまり明らかにされていない。今後の重質 油ガス化技術の方向を明確化するためにも, 石油精製 サイドからの長期的視野に立った提案が期待される。 從来報告されているマクロな把握としては, 海外の 資源についての状海から, 長期的傾向としては, 輸入 原油は重質化し, 石油の需要構造は軽質化すると考え られる11。石油の需要構造の軽質化の進んでいるアメ リカでの低硫黄化および軽質化技術の進展を考えた場 合 $^{10)}$, 今後ガス化の対象となる重質油はますます重質 化するのではないかと思われる。このように考えると， 重質油のガス化技術は石炭のガス化技術との共通の問 題を多く含んで括り，アメリカ，ドイッ，イギリスな ぞを中心とする最近の石炭ガス化技術に注目すべきで あろ ${ }^{13) 14 。}$ 。重質油のガス化はこのよ5に広い範囲 の問題を含んでいるが，プロセスの立場から考えて， ガス化反応による生成物が, @Gas-Solid の場合と, (b)Gas-Liquid-Solid の場合で，技術的な難易度，換 言すると現在までの技術の達成度, にかなり差があ る。すなわち, @については工業的に十分確立された プロセスがすでに存在するのに対して， (bについては 既に工業化されているものもあるが，多くの問題を有 している。かつ, これらの問題は, 重質油（石炭の場 合も含んで）のガス化に際して共通と考えられるがこ の点についてのまとまった検討の報告が少なく, 多く 
の場合“ノウハウ”として問題自身についても討議が なされていない。

重質油のガス化一般については, 森田 ${ }^{15)}$, 国井 ${ }^{16)}$, その他のすぐれた総説があり，かつ，各論については 成書 ${ }^{2}$ もあるので，本稿和いては前述のプロセスと しての共通の問題点についての筆者の考察拉よび経験 を中心に具体例についての報告を述べる。

\section{2. プロセスの問題点}

重質油のガス化についての主な公知のプロセスの一 覽表を表 1 にまとめて示す。

ガス化プロセスの分類は，既に種々の総涚でとりあ げられているが(5)16)，ここでは生成物の相に着目した い。生成物に液相（高温では気相として存在していて も，荻化水素分解生成物の連続組成成分を考慮すると ミストに近い状態のものもあり, 反応器以後に扮いて 分子量の大きいものから温度に応じて漸次凝縮する成 分であり，ここでは $400^{\circ} \mathrm{C}$ 以上の沸点を有する液状物 貿と考える) が存在するか否かでプロセス的にはかな り取り扱いが異なる。

\section{1 生成物が Gas-Soild の場合}

生成物が主としてガスで，少量のカーボンが生成す る例は, 高温部分酸化で重質油を1300 $1400{ }^{\circ} \mathrm{C}$ で分解 し， $\mathrm{CO}, \mathrm{H}_{2}$ の合成ガスを製造する場合である。この 場合にのみ空塔式の反応器が用いられる。ガス化剤に 酸素・スチームが用いられ, 酸素使用量が約 $270 \mathrm{Nm}^{3} /$ $100 \mathrm{Nm}^{3}\left(\mathrm{CO}+\mathrm{H}_{2}\right)$ と高い点が指摘されてはいるが， 重質油を工業的にガス化する装置として稼動している 実䋶あるプロセスである17)。この装置は, 重質油とし て減圧残渣油よりさらに重いものでも処理でき, 熱回 収プロセスも進んでいる。石炭のガス化の場合には, 网の処理技術が問題であうう。THRプロセスは，CaAl 系触媒を用いるスチームリホーマーであるが，操 業条件を選び，かつ $950^{\circ} \mathrm{C}$ 以上の温度条件下（合成ガ スを铱造する場合）では，重質液状の生成がないのが 特徵との卸告がある(18)。リホーマーチューブが $1000^{\circ} \mathrm{C}$ 以上の高温にさらされ，かつ，管型反応器の加熱用燃 料にナフサをたは超低硫黄の燃料を用いる必要がある と考光られる。外熱反応器の場合, 加熱䎲要する燃料 の量が部分燃焼の場合の燃焼部分より多いことも問題 の一つであらう。

THR プロセスでオレフィンを製造することも報告 されているが18)，その場合には 2.2 に述べる種々の問 題を同時に含むことになると考学られる。

2.2 生成物が Gas-Liquid-Solid の場合

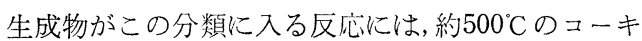

ソグ反応，約 $800{ }^{\circ} \mathrm{C}$ のクラッキングなどがある。主目 的生成物が夜状炭化水素またはオレフインガスに変わ り,さらに反応熱の供給方法が部分燃焼または粒子顕 效いずれによる場合についても共通の問題が存在する。 これらの諸点は, 若干の程度の差はあるにしても, 石 炭のガス化についても同様であろらと考光ている。

反応器として主として用いられるのは, 流動層反応 装置である。流動化粒子は, 軽質油の catalytic cracking 用いられる FCC 触煤のような微粉粒子 $(<100$ $\mu)$ でなく $\mathrm{mm}$ オーダーである。粗粒系流動層の挙 動についての報告が少ないこともあり，解明を要する 点が多い。すなわち，供給された重質油の流動層内へ の分散が問題である。コーキング反応について，処理 能力の表示として（原料油供給速度/流動層内粒子量） の経験值が報告されているが19)，クラッキング反応 器については二，三の例が報告されているのみであ $3^{3 / 4)}$ 。流動層内の粒子の挙動は, とくに部分燃焼に よりガス化の反応熱を供給する場合には，いわゆるホ ットスポットを防止するためにも重要な意味を有して いる。筆者らは, 粗粒系流動層についての粒子の運動 状態改善のために具体的な提案を行なった ${ }^{20)}$ 。粗粒系 流動層に物ける粒子挙動で注目すべきその他の点とし ては，流動化粒子の摩耗の現象がある。流動化状態を 改善するためにガス流速を大きくすると，この現象は 漸次無視しがたい量になる。最近，流動層での石炭の 燃焼と関連して関心が持たれつつあるが，筆者らのデ 一タを近く報告予定である ${ }^{21 。}$

生成物中に前述の液状成分が存在する場合，分解に よって生じた原料油よりもさらに重質な成分が，反応 器内部もしくは反応器出口の transfer line でいわゆ るカーボントラブルを誘発する。この現象は，いわゆ るコーカーからクラッカーに至る種々の反応装置まわ りで発生している本質的な工業装置のトラブルである のに, 従来, 組織的な検討は注とんど報告されていな い。この現象をコーキング反応として把握し，この機

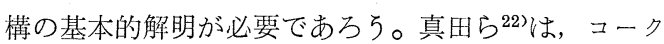
の製造㐨よびその品質改良のためこの現象を別の立昜 から取り扱っているが，筆者らはこのコーキング反応 を，重質物の性質と関連させて速度論的に検討した ${ }^{232} 。$ この液状成分のカーボントラブルの対策として, transfer line を高温に保持して凝縮を防止することが工 業的には考案されているが，本質的な解決にはならな いと考光る。この対策として，分解炬に接続してコ一 キング反応を意図的促促するためのクェンチャ一 （流動層型式）が有効であ万弓 ${ }^{4)}$ 。 


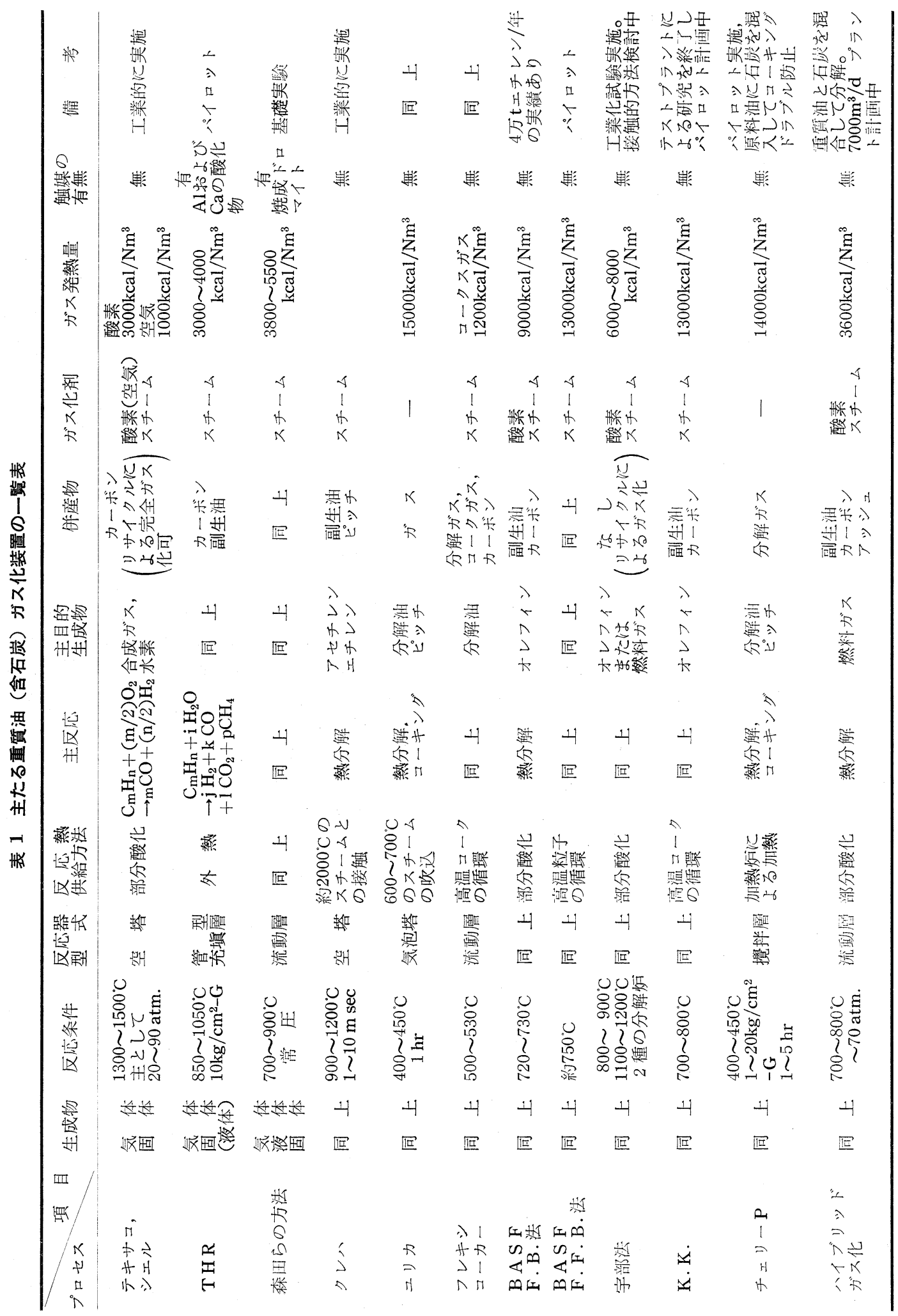




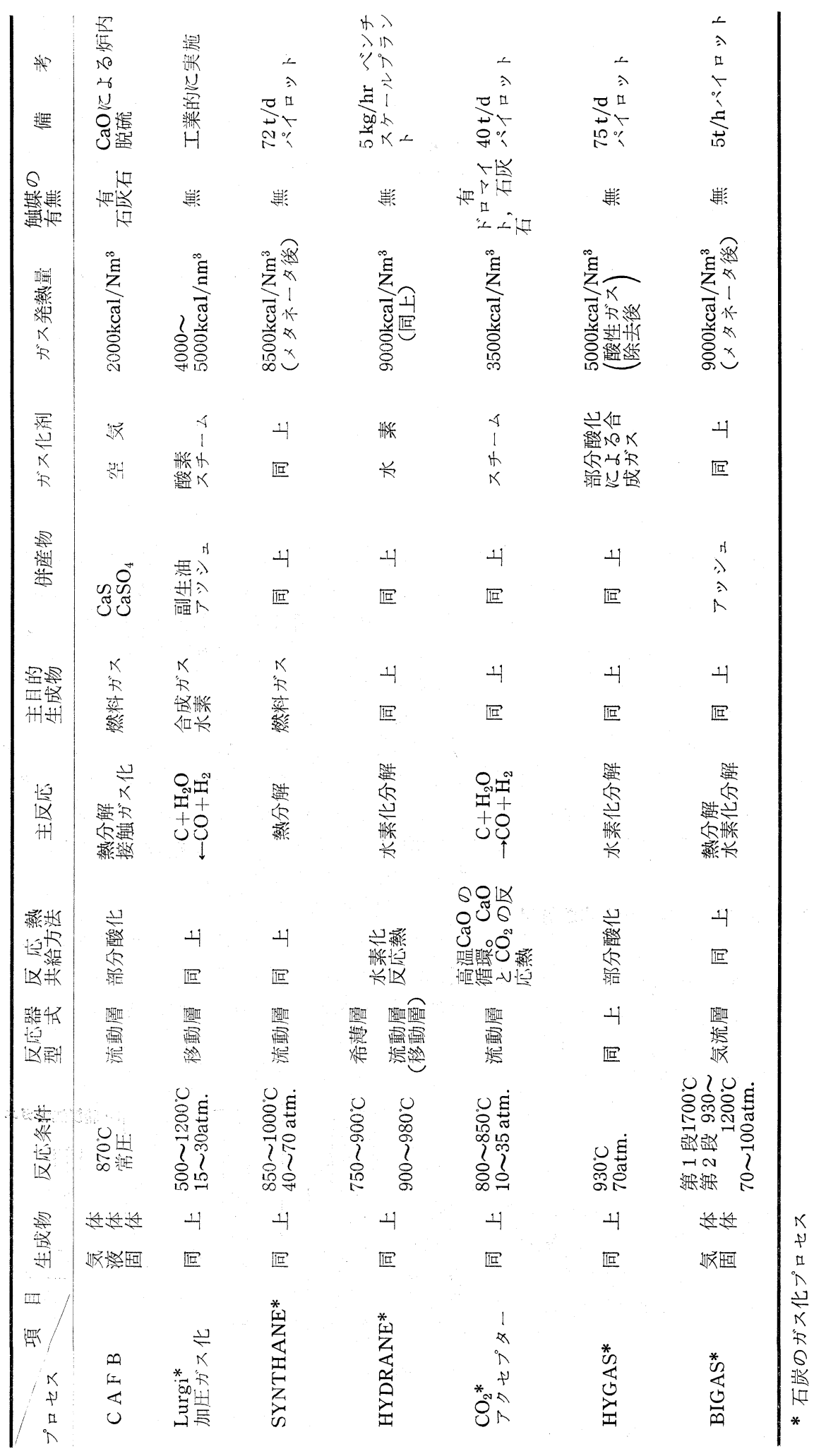


カーボントラブルは, 石炎のガス化により高カロリ 一ガスを製造するプロセスでも同様に生じて抮り24), この対策の一層の研究が望まれる。

重質油のガス化プロセスの今後の注目すべきもら一 つの方向は, 熱分解反応に際しての触媒利用である。 この方法の研究としては, 森田らのドロマイトを用い る方法 ${ }^{25)}$ ，Esso の脱硫とガス化を同時に実施する方 法 ${ }^{26)}$ などがある。ガスオイルの熱分解にゼオライトを 用いる方法と関連して, コークスの生成過程と触媒効 果が検討されている27)。前節で述べた THR も同様の 方向の試みであろう。

石炭のガス化についても, Exxon の $\mathrm{K}_{2} \mathrm{CO}_{3}$ 触媒の ように接触ガス化の傾向が出てきている。

石炭と重質油のガス化の関係についてここで簡単に 述べるが，石炭の場合，灰の挙動が重質油の場合の問 題点に加えて注意しなければならないことである。

2.1 に示したような高温でガス化した場合, 液状生成 物の副生は防止できるが，灰分の溶触が生じ，例えば Slag bed のようなプロセスにならざるをえない。1000 C C以下で石炭のガス化を行なった場合，本節で述べた 諸点が灰分以外に問題になっている28)。前処理で石篇 を完全に dry char にして拉いてからガス化するプロ セス ${ }^{299}$ は, 問題点を別々に処理するという意味で, 方 向としては一つの実際的な解決方法ではないだろうか。 これとは別に, 重質油と石炭の混合スラリーをガス化 するプロセスも報告されて和り ${ }^{30)}$ ，この場合は問題点 を多面的に解決しょうとする方向のプロセスとして注 目される。

\section{3. 流動層を用いるガス化プロセスの問題点の解明 の具体例}

これまでは種々のガス化プロセスの概念やそれらに 共通する問題点について述べてきたが，以下には筆者 らがガス化脱硫工業化試験設備の建設, 運転に当たっ て経験したいくつかの基本的な問題点について述べる とともに，その解決のために実施した実験結果をも交 えて対応策について言及したい。

\section{1 プロセスの概要}

宇部式重質油ガス化脱硫プロセスは，原油分解によ るオレフイン製造プロセス4) の展開であり, 既に筆者 の報告 ${ }^{3132)}$ があるのでここでは概要にとどめる。フ ローシートを図 1 亿示す。ガス化炉は 3 段の流動原を 垂直に接続して構成されており, 下部が高温分解炉, 中間部が通常分解炉，上部がクェンチャ一である。原 料残渣油は通常分解椨に供給され，800 900 C で分解 される。分解によって生成するガス状, 液状物質特よ
びカーボンの5ち, 副生重質油稆よびカーボンはリサ イクルされ，宲温分炉で 1100 1200C でガス化され る。これら高温分解炉特よび通常分解炉にはガス化剂 として酸素とスチームが供給され, 部分燃焼により反 忍熱が供給される。クェンチャ一では副生重質油を直 接層内に供給することにより生成ガスの冷却を行なら とともに, 流動化粒子表面に炭素質物質を付着させる。 クェンチャ一内でカーボンが付着した粒子は, 粒子循 環ラインを経て高温分解炉に循環され, 付着物がガス 化される。すなわち, 流動化䊀子は高温分解炉一通常 分解炉一クェンチャー一高温分解炉と循環する。本プ ロセスで用いる流動化粒子は, シリカ, アルミナを主 成分とする粒子であり, 流動層焼成炉によって製造さ れる。形状は球に近く, 圧縮強度が大であり, かつ適 度に多孔性である。このため, 耐摩耗性呿よび耐スポ ーリング性がすぐれている。無機酸化物粒子の使用と 部分燃焼方法の採用により, 分解条件の選択に際して 自由度が大きい。とくに, 高い温度と短い滞留時間が 要求される ${ }^{33)}$ オレフイン製造に容易に対応できる。さ らに, 後述の強制循環流型流動層の採用により, 分解 炕単位容積当たりの原料油処理能力が火きいといら特 徵を有する。

ガス化工程の生成物は, 蒸留工程に捛いてガス, 軽 質留分拈よび重質留分に分離されたのち，ガスは脱硫 工程に送られガス中の硫黄分が単体硫黄として回収さ れる。脱硫された精製ガスは，オレフィンに富んだ高 い発熱量を有するガスであり，無公害燃料ガスとして 既設のボイラーに使用できる。

3.2 流動化状態

本プロセスで使用されている強制循環流型流動層の 概念図を図 2 に示す。図に示されるように，ガス整流 板を通じて供給される流動化ガスとは別に, ガスジェ

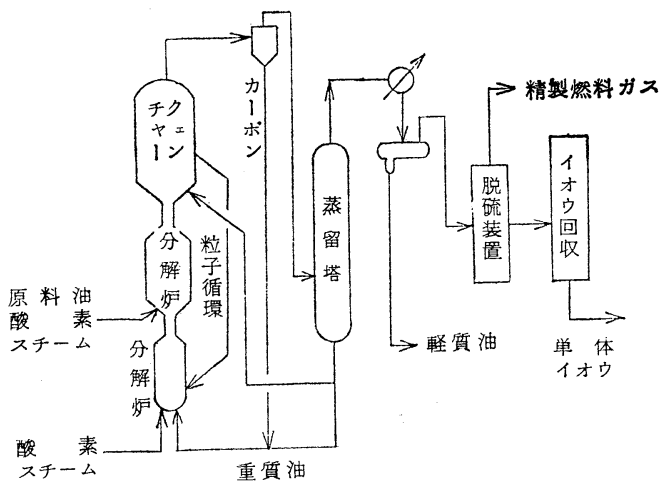

図 1 宇部式ガス化脱硫装置 


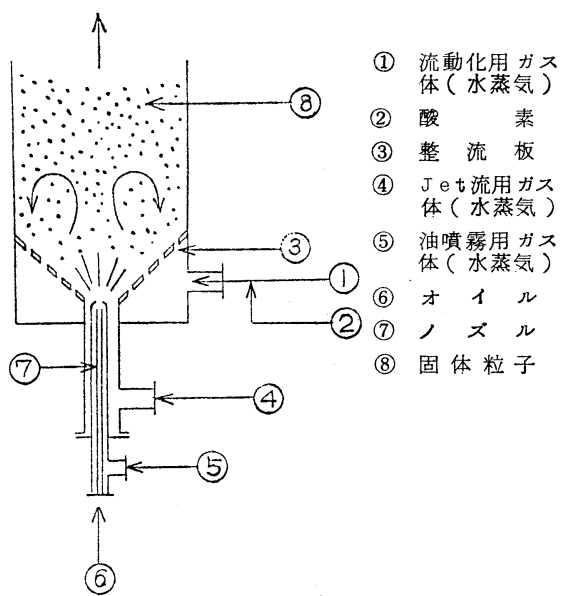

図2 分解炉の模型図

ット流ノズルを通じて流動化ガスの一部を直接流動層 内に供給する。このガスジェット流により, 流動化粒 子は層内中心部で上昇, 壁近傍で下降する暊内循環運 動をする。流動層内に液体を供給して燃焼, ガス化な どを行な特与とする場合, 液体をいかにして層内に均 一に分散させるかが重要な課題であり, 上述の強制循 環流動層はこの目的に対して非常に有效な手段であ る。

また, ロート状ガス整流板の使用により, 壁近傍を 下降してきた粒子をすみやかに層中心部に移動させる ことができる。これに対し, 通常の流動壓ではガス整 流板と層壁の接点近くにデッドゾーンを生じやすく, 粘着性のある粒子では集塊化, また燃焼反応の起こる 系ではホットスポットの生成などの原因となりやす い。さらに, この部分は, 特に高温の系に执いてガス 整流板に大きな熱応力がかかりやすく, ホットスポッ トの生成はこの面でも大きな問題となる。

流動化状態と関連して, 特に工業装置で重要となる 問題の一つに流動化粒子の摩耗がある。予想されるよ らに, 粒子の摩耗速度は流動層内ガス流速により著し く変化する。一例を図 3 に示した。図 3 は, カーボン 付着のない粒子を常温の空気を用いて流動化させた場 合の結果であり，実験に用いた装琶は $105 \mathrm{mm \phi}$ の嘪 流層型流動層である。これより, ガス流速に対し 2 乗 もしくは 3 乗で相関できることがわかる。ここでガス 流速として, ロ一ト状部分に梪㲿るガス流速の変化を 考慮した平均ガス流速をとることにより, 種々の流動 層蛒よび噴流層について統一的に取り扱うことができ る。このようにガス流速が粒子摩耗に大きな影響を及 ぼすという観点からは, 低流速が望ましい。他方, 低 流速では流動化が緩慢となり前述のようなトラブルを

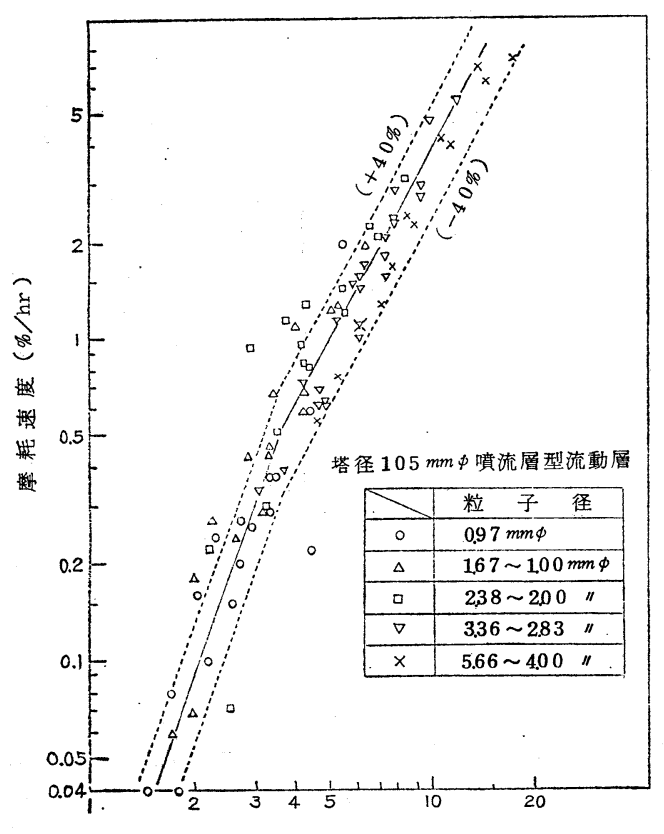

平均ガス流速: $\overline{\mathrm{u}}(m / \mathrm{sec})$

\section{図 3 噴流層型流動化装置での摩耗速度}

生じやすい。したがって, 問題は低流速に括いていか に良好な流動化状態を保ち、デッドゾーンをなくすか という点に集約される。この問題について, 装置の形 状, 流動化条件を変化させてモデル実験を行なったの でつぎにその概要を記す。

実験装置を透明塩化ビニールで製作し, ガス整流板 の拡がり角度和よび粒子径を变えて目視による観察を 行なった。結果の一例を図 4 亿示す。すべり開始線は, 図 4 中のデッドゾーンの消滅する時点に捛けるガス流 量を結んだものである。図中の $\mathrm{V}_{\mathrm{A}} \mathrm{V}_{\mathrm{N}}$ 呿よび $\mathrm{V}_{\mathrm{m} f}$ は，それぞれガス整流板を通じて供給されるガス量， ガスジェット流として值接層内に供給されるガス量抒 よび流動化開始速度に対応するガス量を表わしている。 図 4 より, 口一ト状整流板の拡がり角度の影響の大き いことが明らかである。この図は粒径が $0.5 \sim 1.68$ $\mathrm{mm} \phi$ であるが, 他の粒径でも同様の傾向である。た だし, $5 \mathrm{~mm} \phi$ 程度の大粒径では上記拡がり角度の影 響は小さくなる。

実装置に和汁る流動化粒子にはカーボソが付着して いるため, 摩耗速度は単なる粒子の摩耗とは違い, カ 一ボンの付着の程度によって変化する。この様子をカ 一ボン付着粒子について常温空気で流動化させた結果 の一例を図 5 に示す。粒子のカ一ボン付着率の増大に 伴い, カーボンの摩耗速度は增大するが, 付着率が約 


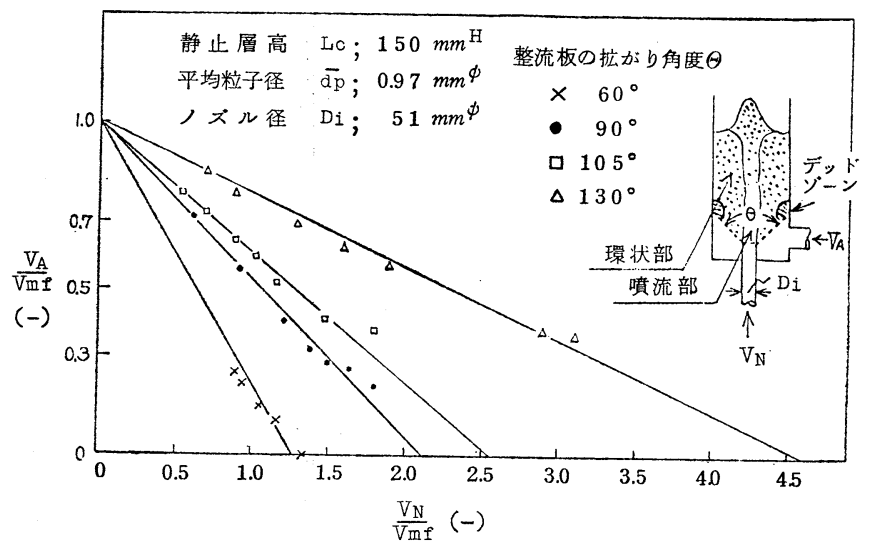

図 4 すべり開始点と $\mathrm{V}_{\mathrm{A}} / \mathrm{V}_{\mathrm{m} f}$ および $\mathrm{V}_{\mathrm{N}} / \mathrm{V}_{\mathrm{m} f}$ の関係

4 \%に達するとほほぼ横ばいとなる。一方, 粒子の摩耗 速度は, カーボン付着率の增大とともに急速に減少 し, カーボン付着率が $5 \%$ で $1 \mathrm{~g} / \mathrm{hr}$ となる。これは 流動層内粒子ホールドアッブに対し約 $0.1 \% / \mathrm{hr}$ に相 当する。

工業化試験設储に括汀る粒子摩耗速度とカーボン付 着率の関係を図 6 亿示す。カーボン付着率が $15 \%$ 以上 で摩耗速度は精子ホールドアッブに対し $0.5 \% / \mathrm{hr}$ 以 下であった。

このように，粒子の摩耗は流動化状態と粒子へのカ 一ボンの付着の程度によって律せられる。流動化条件 については, 構造面での検討を行なった結果, 粓子摩

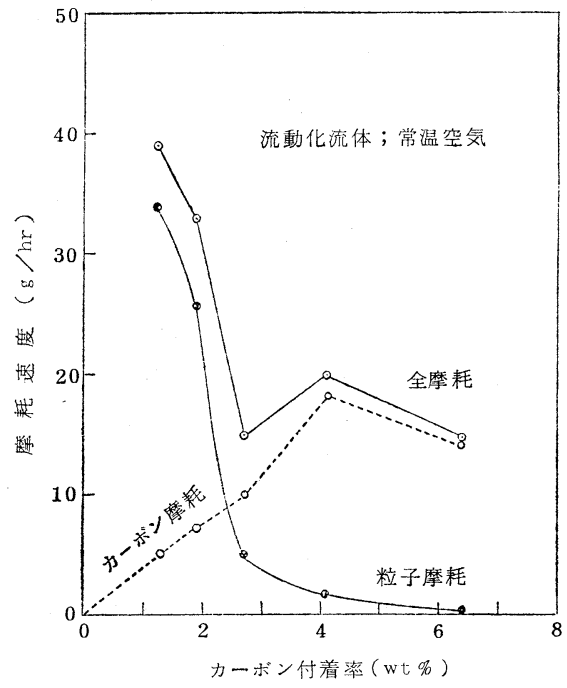

图 5 粒子およびカーボンの摩耗速度と カーボン付着率の関係
耗を大幅に低減できることがわかった。

実装置に和ける粒子の摩耗は, 粒子ホールドアップ の関係からその多くをクェンチャーが占める。このた め,クェンチャーに拉けるカーボン付着の促進沶よび 上記の構造的改良により，実用上問題とならぬ程度に まで粒子摩耗を低減できる見通しを得た。

3.3 transfer line に括けるコーキング

重質油を 800 $900^{\circ} \mathrm{C}$ で熱分解する埸合，生成物は 炭素数の小さいガスから炭素数の非常に大きい重質油 さらにはカーボンに至るまで広く分布している。した がって，上記のような分解条件下に标いては，transfer

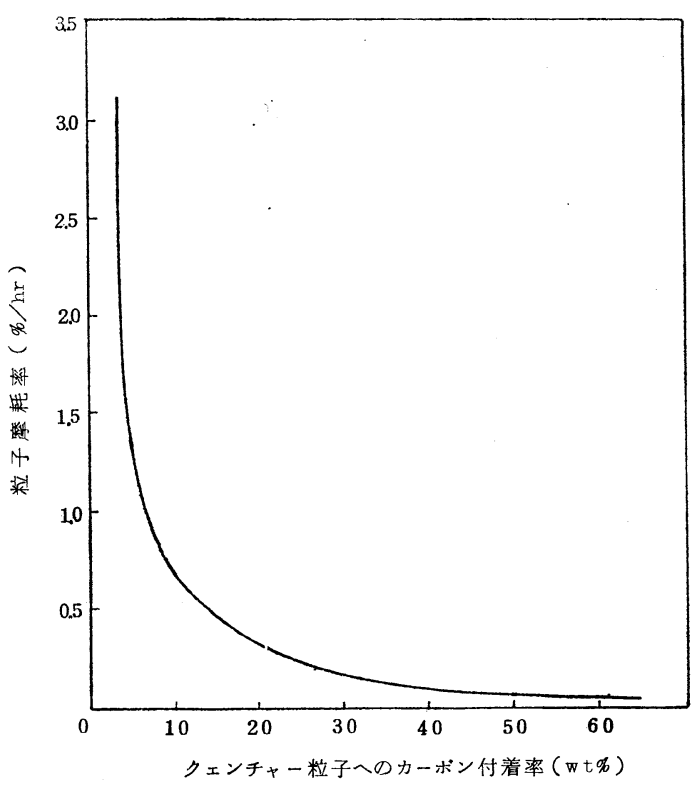

図 6 粒子摩耗率とカーボン付着率の関係 
line への重質物の析出ならびにそれら重質物のコー キング反応によるさらに重質な物澌への変化について は，ある程度是恋しなければならない。すなわら， transfer line の形状や line 内流速に特に配慮をする こと执よび十分な保温を行なって析出を抑制すること は，それ自体有效なるのではあるが，決定的な解決法 とはなりえない。これに対する決定的な解決策は，熱 的に安定な油による line 内洗浄である。工業化試験 設備に拉いては， line 内洗浄を行なった部分につい ては全くカーボンその他の付着は認められなかった。

クェンチャ一出口から油による洗浄部分に至る line 特よび機器については, line の形状に注意を払 5 と ともに, on-line デューキングによる付着防止を図っ た結果，この部分の閉そくによるトラブルを防止する ことができた。

\section{4 クェンチャーの意義}

オレフィンを目的とした熱分解に限らず, 副反応の 防止の面から分解生成物の急冷は重要なポイントであ る。本プロセスでは, 前述のように分解炉に直結して 噴流層型クェンチャーを設置したため, 生成物は極め て短時間のうらに副反応の生じない温度レベルまで冷 却される。クェンチャーでは, 冷却に伴って流動化粒 子の表面にカーボンおよび重質成分が付着する。粒子 表面に重質成分の付着が生じることにより，次に示す 3つの利点がある。

(1) クェンチャー以後のガス流中に同伴されるカー ボンおよび重質成分が減少するので, transfer line のカーボントラブルを少なくできる。

（2）炭素質物質の付着した粒子は高温分解炉に循環 されるが，ここで主として部分燃焼用に供給された 酸素と反応し，炭素質物質の炶内ガス化（燃焼）が 行なわれる。これは分解に必要な反応熱の相当部分 が炭素質物質の燃焼によってまかなわれることであ

り，プロセス的に有利である。

（3）粒子の摩耗速度を大幅に低減できる。

(2)に関する基礎実験の概要を次に示す。実験装置は, 図 7 に示されるよ5に内径約 $100 \mathrm{~mm} \phi$ の流動層であ り，外熱式と部分燃焼式を組又合わせた実験ができ る。すなわら, 所期の部分燃焼の程度に対応する量の 酸素を供給し, 外部加熱の調整により分解温度を維持 する。この装置により部分燃焼の程度を変化させて生 成物収率の変化を検討した結果を図 8 亿示す。原料油 はミナス常圧残椬油であり, 流動化粒子には砂を用い た。図 8 より, 部分燃焼を行なった場合, 通常目的成 分とされるオレフィン执よび軽啠油の収率には差がな

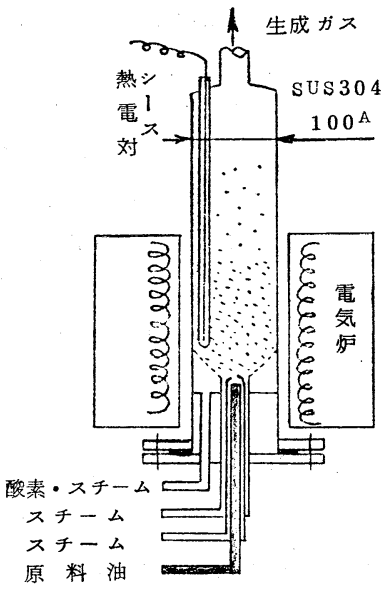

図 7 分解炉概略図

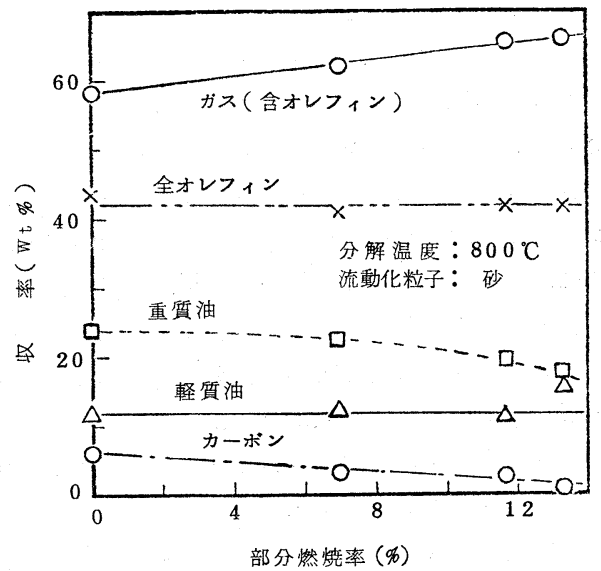

図 8 収率之部分燃焼率の関係

（ミナス常圧残渣油）

く，重質成分の燃焼によりその収率が低下することが わかる。

流動化粒子への見掛けの付看速度は, 真の付着速度 预よびはく離速度の差として定まる。真の付着速度は, 付着の対象となる成分の性状や層内温度によって決ま り, はく離速度は前述のよ5に装置構造特よび流動化 条件によって定まる。付着速度をコーキング反応機構 と関連づて説明するため, 㳄に示す 1 次不可逆反応 モデルに基づいて反応速度:定数を求めた ${ }^{23)} 。$

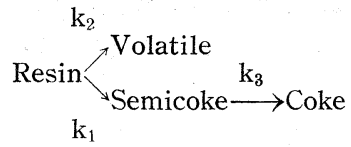

ここで Resin, Semicoke 括よ゙ Coke をそれぞれ 浴郕分別による BS (ベンゼン可浴) 分， BI-QS（ベ 
ンゼン不溶, キノリン可溶）分蛙よび QI（キノリン 不溶) 分とする。Volatile とは, Resin が反応するこ とによって生成する揮発分を指す。上記モデルが実験 結果を最も良く表わすように, 各ステップの反応速度 定数 $\mathrm{k}_{1}, \mathrm{k}_{2}$ 物よび $\mathrm{k}_{3}$ を電子計算機を用いて求めた。 一例としてミナス常圧残渣油を熱分解して得られた副 生重質油（特性係数 ${ }^{34}$ ) $\mathrm{K}=9.3$ ) 飞ついて求めた $\mathrm{k}_{1}, \mathrm{k}_{2}$ 特よび $\mathrm{k}_{3}$ のアレニウスプロットを図 9 に示す。特性 係数の異なる種々の油について同様の実験を行ない， 度数因子和よび活性化ェネルギーと特性保数の間に良 好な相関を認めた ${ }^{23) 。}$

3.5 流動層の安定性

多段流動層の工業的実施に当たり, 各流動層が安定 して運転できることが不可欠である。本プロセスでは, パイロットプラント秝よび工業化試験設備いずれに招 いても安定な運転ができた。

一般に，流動層を絞り部を介して上下に接続した場 合，雨層間に粒子の移動を生じる。すなわち，下の層 から上の層への粒子の飛び出し拉よび逆に上の層から 下の層への粒子の落下である。飛び出し速度に関係す る因子としては，下の層の粒子ホールドアップおよび ガス流速が，粒子の落下については絞り部のガス流速 および上の層の流動化状態がある。したがって, 要求 される負荷の変動に対し安定な運転ができるよ5に, 上記諸条件を決定する必要がある。

モデル装置を用いて粒子の飛び出し速度と凮内粒子 ホールドアップの関係を求めた結果の一例を図10に示 す。図10はある特定の装置に捛いて, 粒子径和よびガ ス流速を固定して得られたものである。眓からわかる ように，層内粒子ホールドアップが增大すると飛び出 し速度が急增する。すなわち, 上の層からの粓子の落 下が増加しても, 逆に減少しても速やかに平衡值に迋 することが理解される。同様のことが実装置でも起こ る。しかしながら, 層相互間で粒子の移動が生ずるこ とは, 本プロセスのように凰間に温度差がある坋合に は熱の移動を伴うこととなり，プロセス的には好まし くない。したがって，適当最の粒子の移動が生ずる装 置条件を選ぶ必要はあるが，系怕自己安定性を有して 括り運転に困難を伴うことはない。

\section{4. 高温部分然焼による重質油のガス化}

テキサコ法捛よびシェル法として知られる高濫部分 燃焼法は，1950年代初期に工業プラントが稼動して物 り，以来世界各国に捛いて非常に多数の実績を有する 方法である。反応は上記いずれのプロセスでも同じで あり, 総括的に次式で示される。

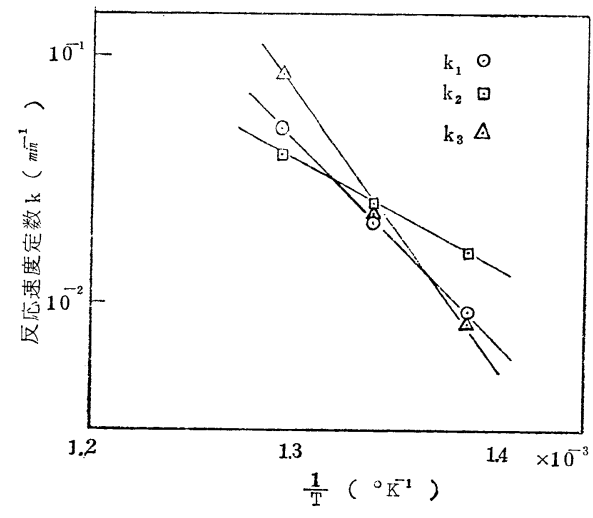

図 9 反応速度定数と温度との関係

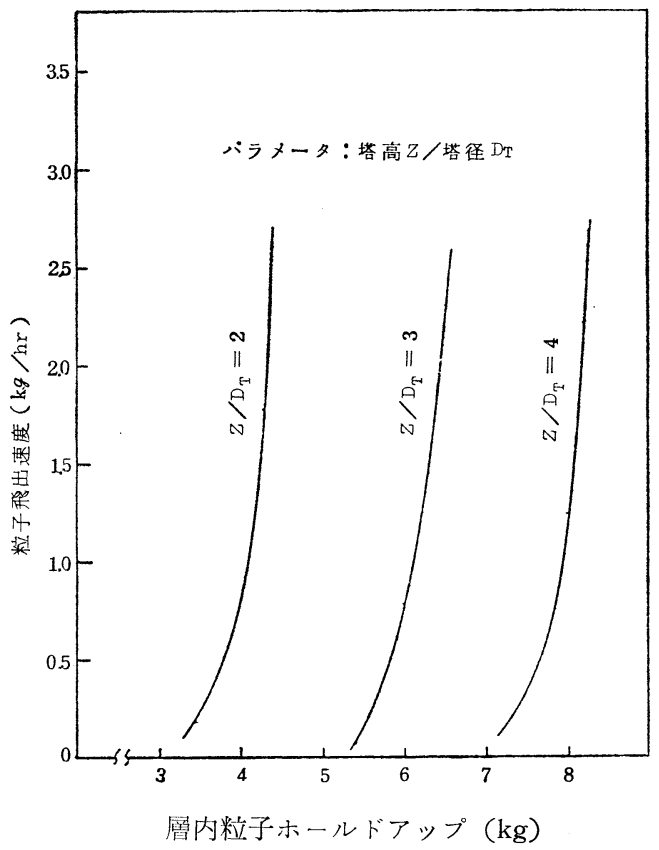

図10 粒子飛出し速度と層内ホールドアップの関係

$$
\mathrm{C}_{m} \mathrm{H}_{n}+(\mathrm{m} / 2) \mathrm{O}_{2} \longrightarrow{ }_{m} \mathrm{CO}+(\mathrm{n} / 2) \mathrm{H}_{2}
$$

実際には, 原料炭化水素が酸素と反応する第 1 段階 （発熱）呿よびそれに続く，原料油が水蒸気ならびに 炭酸ガスと反応寸る第 2 段階（吸熱）上り成り，それ らが同一のガス化炉内で進行する。

この方法の特徴は, 原料岑化水素の種類が問われな いことであり，ガス状炭化水素から真空残渣油まで処 理することができる。したがって，競合プロセスであ るナフサのスチームリホーミングとの比較は, 最終的 にはどちらが経済的かに集約される。高温部分燃焼方 法は, ナフサのスチームリホーミングにくらべ，空父 分離装置の設置㘧よびそれに伴うェネルギー消費の增 
表 2 原料油の性状

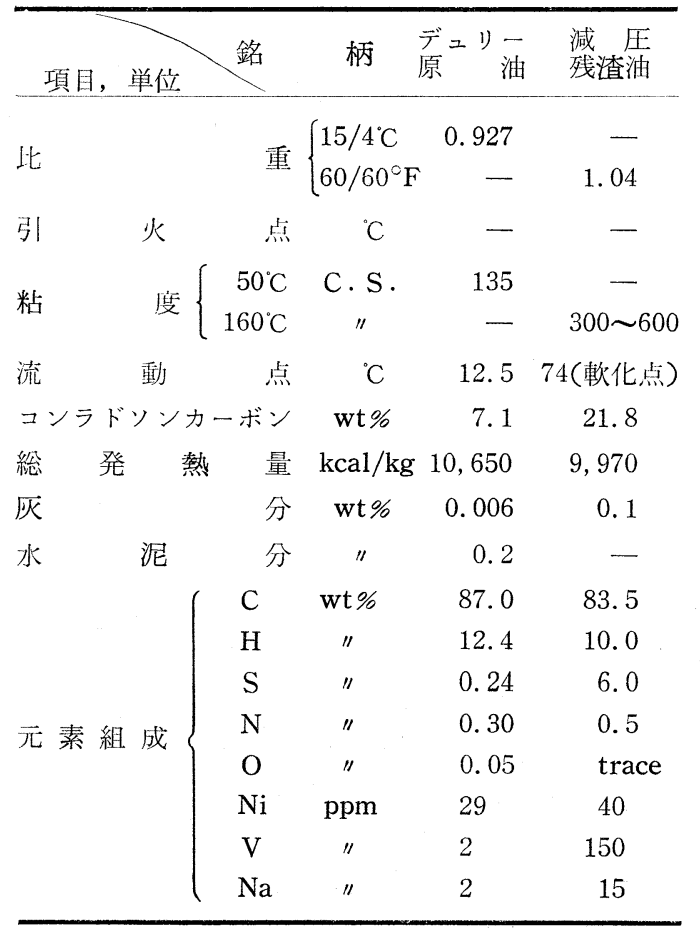

\section{表 3 運転実績比較}

\begin{tabular}{|c|c|c|c|c|c|}
\hline \multicolumn{2}{|r|}{ 単 } & 毛位 & 油銘柄 & $\begin{array}{l}\text { 原ニリー } \\
\text { 油 }\end{array}$ & $\begin{array}{l}\text { 減 压 } \\
\text { 渣油 }\end{array}$ \\
\hline 原 & 料 & 油 & kl & 0.800 & 0.819 \\
\hline 燃 & 料 & 油 & " & 0.077 & 0.067 \\
\hline 酸 & 素 & $(96 \%)$ & $\mathrm{Nm}^{3}$ & 605 & 620 \\
\hline 発 生 & ガ & ス 量 & $\mathrm{Nm}^{3} / \mathrm{t}$-oil & 13,075 & 2,850 \\
\hline \multirow{3}{*}{\multicolumn{2}{|c|}{ 発生ガス }} & $\mathrm{H}_{2}$ & vol \% & 48.2 & 44.93 \\
\hline & & $\mathrm{CO}$ & " & 42.5 & 45.43 \\
\hline & & $\mathrm{CO}_{2}$ & " & 7.3 & 6.72 \\
\hline \multirow[t]{3}{*}{ 組 成 } & & $\mathrm{CH}_{4}$ & $" \prime$ & 0.4 & 0.25 \\
\hline & & $\mathrm{N}_{2}+\mathrm{Ar}$ & $"$ & 1.6 & 1.20 \\
\hline & & $\mathrm{H}_{2} \mathrm{~S}$ & " & 0.04 & 1.47 \\
\hline
\end{tabular}

大といら面で不利である。したがって，高温部分燃焼 方法が経済的に成立するかどうかは，上記によるコス 卜差を原料油の価格差によって吸収できるかどらかに かかってくる。公害規制が緩やかであった時点では,

減圧残渣油のよ5な重質留分は重油のブレンド材とし てカットバックされていたが，規制の強化に連れて何 らかの形でこれを処理する必要が生じてきた。刘応策 としては, 従来の直脱をさらに進めたプロセス、 コー キング反応を含むプロセスなどが開発，工業化されて いる。これらのプロセスは，重質留分を処理して主と
して軽質留分を得るものであり, 結果的に両者の価格 差を拡大するものである。このような状況から考觉れ ば，重質留分の高温部分燃焼による合成ガス製造が経 済的に成立する条件は整って赫り，今後この傾向㹥さ らに進むるのと予想される。

当社に招いては，アンモニア用水素源として昭和 35 年にテキサコ法を採用し，以来低硫黄分のデュリ一原 油を原料油として使用していた。しかしながら，上記 の観点から重質油の余㮃を予測し, 昭和 47 年に原料油 を減圧残渣油に変更した。デュリ一原油および減圧残 渣油の性状を表 2 亿, 運転実績を表 3 亿示す。結果は 良好で, 原料油転換以来順調に運転を続けている。本 設備は旧設備の転用であるため, 一般的な意味では最 適なフローとなし得なかった。今後の重質油の高温部 分燃焼方法を考えるならば，操業圧力の選定，廃熱ボ イラー方式かクェンチ方式かの選択, 硫黄分に強い $\mathrm{CO}$ 変成触媒の使用, 酸性ガス除去プロセスなどにつ いて十分検討を行ない，目的に最も適した方式を採用 する必要がある。

高温部分燃焼の応用として，メタネータを使用する ことなく比較的高いメタン含有率を有するガスを得る

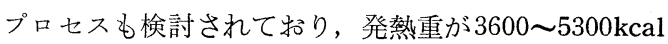
$/ \mathrm{Nm}^{3}$ のガスが得られるといら報告がある ${ }^{35)}$

\section{5. おわりに}

重質油のガス化の位置づけは, 社会的要請およびェ ネルギー, 資源の状沉により変化する石油精製システ ムの状況により規定される。石油危機以降の諸情勢の 変化の中で, 重質油のガス化プロセス汇要請される条 件は，技術的により難しくならざるをえないである ら。この意味で, 従来までに知られているプロ七スの 共通の問題点を展望し, その解決方法について考察を 行なった。わが国でこれまでに蓄積された重質油のガ ス化技術は，重質油のガス化が石炭のガス化とかなり 近い関係を有しているので, この面での展開も今後に 期待される。

\section{交献}

1）化学工学協会産業部門委員会 1014 エネルギー経 済開発専門委員会 第 1 次調查解告書, 昭和 49 年 3 月

2）燃料協会 重質油ガス化委員会編, 重質油のガ 又化(1973)

3) A. Steinhofer, Chem. Ing. Tech., 36, 889 (1964)

4) T. Matsunami et al., Hydroca. Process., 49, 
(11), 121 (1970)

5）国井大蔵, 功刀泰碩, 石油誌, 16, 834 (1973)

6)) T. Hosoi, H. G. Keister, Chem. Eng. Progr., 71, (11), 63 (1975)

7) 上野高份, 石油誌， 16, 844 (1973)

8）真田宏, ibid., 15, 42 (1972)

9）野島肖吾, 若林幹雄, ibid., 15, 47 (1972)

10) 中村宗和, ibid., 20, 379 (1977)

11) 山口隆章, 化学工学, 38, 551 (1974)

12）清水固, 燃協誌, 52,12 (1973)

13）森田義郎, ibid., 53, 239 (1974)

14) 国井大蔵, 石油誌, 17, 857 (1974)

15) 森田義郎, 化学工学, 40,340 (1976)

16）国井大蔵, ibid., 38, 697 (1974)

17）末山哲英，アンモ二アと工業，26，(3), 1 (1973)

18) T. Tomita, M. Kitagawa, Chem. Ing. Tech., 49, 469 (1977)

(19 K. A. Kobe et al., Advances in Petroleum Chemistry and Refining, Vol. 2, Interscience, New York, 1959

20）化学工学協会 第43年会にて発表予定

21) 同上

22）真田雄三ら, 石油誌, 15, 936 (1972)

23) 久富勝機, 中井成行, 河野佾志, 石油誌投稿中

24) W. P. Haynes, J. P. Strakey, R. R. Santore,
R. Lewis, Paper Presented at the Fourth Annual International Conference on Coal Gasification, Liquefaction \& Conversion to Electricity, Aug. 2-4, 1977

25）森田義郎ら, 石油誌, 19, 285 (1976)

26) R. E. McMillan, F. D. Zoldak, R. L. Gamble, B. L. Simon, Paper Prepared for Spring Technical Meeting of The Combustion Institute. 1976

27) T. M. John et al., Advancement Chem. Ser. Bd. 133, P. 422 (1974)

28）資源協会 海外の石炭の利用技術調雀湳告書, 1977

29) K. H. van Heek et al., Chem. Ing. Tech., 46, 937 (1974)

30) 平戸瑞穂, 小栗敬堯, 宮寺博, 化学工学, 41, 211 (1977)

31）河野合志, ibid., 38, 710 (1974)

32）河野台志，石油誌 16, 839 (1973)

33) J. Wengler, H. Zeininger, Chem. Ing. Tech., 33, 301 (1961)

34) W. L. Nelson, Petroleum Refinery Engineering, McGraw-Hill, 1958

35) W. L. Slater, A. M. Robin, W. G. Schlinger, 石油誌, 16, 852 (1937)

\title{
On the Critical Process Problems by the Gasification of Residual Oils
}

\author{
by Hisashi Kono \\ (Ube Industries, Ltd.)
}

SYNOPSIS:- The critical problems which are common by the various gasification processes of the heavy residual oils and coals were discussed from the chemical engineering viewpoint.

The fundamental and engineering approaches to these problems were proposed based upon the experiences of $250 \mathrm{t} / \mathrm{d}$ gasification plant. 